\title{
Impact of Sea Level Rise Due to Climate Change : Case Study of Klang and Kuala Langat Districts
}

\author{
M. F. Mohamad, M. R. Abd Hamid, N. A. Awang, A. Mohd Shah, and A. F. Hamzah
}

\begin{abstract}
Global climate change is predicted to cause an increase in sea level rise and the frequency and size of storms and storm surge. This will contribute further to the shoreline erosion; flood damage, inundation of land, saltwater intrusion into the freshwater lens aquifer, among others. The completion of sea level rise study in Malaysia by National Hydraulic Research Institute of Malaysia (NAHRIM) and Ministry of Natural Resources and Environment (NRE), several subsequent studies were proposed. One of the subsequent studies is a study on the sea level rise impact to the planning and development of the national coastal zones specifically at Klang and Kuala Langat districts. Concurrently, a study on the National Physical Plan - Coastal Zone (NPP-CZ) was prepared by the Federal Department of Town and Country Planning Malaysia. The national level study has set clear principles and strategies on coastal spatial planning and developments along the national coastline (Peninsular Malaysia).
\end{abstract}

Index Terms - Sea level rise, climate change.

\section{INTRODUCTION}

The coastal population of Peninsular Malaysia has experienced a rapid growth in the past two decades. As rapid population as well as economic growth is projected to persist, especially within the coastal conurbations and urban centres, development pressure is expected to continue to be high in the next decade. Coastal land is a valuable resource that has important economic, social, cultural and ecological values. Poor planning decisions with limited understandings and input on coastal processes and risks can result in the degradation of coastal resources and disruption to natural coastal processes thus greatly altering the shape of the coastline, and consequently resulting in erosion (loss of land), lost development opportunities, decrease in land value, as well as increased exposure of human life and property to coastal hazards. Global climate change is predicted to cause an increase in sea level rise and the frequency and size of storms and storm surge. This will contribute further to the shoreline erosion; flood damage, inundation of land, saltwater intrusion into the freshwater lens aquifer, among others.

Sea level rise (SLR) over the global system has been studied by various observations during the historical period, and by Atmosphere-Ocean coupled Global Climate Models or General Circulation Models (AOGCMs) during 2000 - 2099 [1]. Historical observations of the sea level change have been performed either by tidal gauges [2] or by satellite altimetry

Manuscript received December 21, 2016; revised January 21, 2017.

The authors are with the National Hydraulic Research Institute of Malaysia, Lot 5377, Jalan Putra Permai, 43300 Seri Kembangan, Selangor, Malaysia (e-mail: fauzi@nahrim.gov.my, radzi@nahrim.gov.my, aslinda@nahrim.gov.my,

ahmadfarhan@nahrim.gov.my).
[3]. Based upon analyses of the tidal gauge records, Church et al. [4] determined a global mean SLR of $1.8 \pm 0.3 \mathrm{~mm} / \mathrm{yr}$ during the 1950-2000 period, and Church and White [5] determined a mean SLR of $1.7 \pm 0.3 \mathrm{~mm} / \mathrm{yr}$ for the 20th century. Considering these results and allowing for the gradually increasing trend in recent years by satellite altimetry observations, Bindoff et al. [6] assess the global mean SLR rate to be $1.8 \pm 0.5 \mathrm{~mm} / \mathrm{yr}$ for the 1961-2003 period, and $1.7 \pm$ $0.5 \mathrm{~mm} / \mathrm{yr}$ for the 20th century. In context of Malaysian region, the rate of SLR varies throughout the whole coast of Malaysia with an average between $2.73-7.0 \mathrm{~mm} / \mathrm{yr}$ based on the analysis of satellite altimetry data during 1993-2010 [7]. These rates was assimilated with the results from 49 simulations of the 7 Atmosphere-Ocean Coupled Global Climate Models (AOGCM), which results in the projection of 2.5 to $5.2 \mathrm{~mm} / \mathrm{yr}$ for Peninsular Malaysia; 4.3 to $5.9 \mathrm{~mm} / \mathrm{yr}$ for Sarawak; and 6.3 to $10.6 \mathrm{~mm} / \mathrm{yr}$ for the State of Sabah [7].

The aim of this paper is to assess the impact of SLR due to the climate change to the planning and development of coastal zones. The study will prepare a guideline on the coastal and estuary future land use zoning and adaptation measures to reduce impact of SLR due to climate change for Mukim Kapar, Mukim Klang and Mukim Jugra, which are located within the Districts of Klang and Kuala Langat, Selangor, Malaysia.

\section{CASE STUDY}

\section{A. Study Area}

The selected area for SLR case study covers Mukim Kapar, Mukim Klang and Mukim Jugra, located within the Klang and Kuala Langat Districts, Selangor, Malaysia as shown in Fig. 1. The study area falls in Klang and Kuala Langat coastal zone which extends further inlands, with the total area coverage of 80,966 hectares. Area coverage are based on the three scenarios as shown on Table I.

The coastal zone is essentially the interface between land and sea. As a precise line that can be called a coastline cannot be determined due to the dynamic interaction between the force of nature and geology, the term "coastal zone", which refers to the spatial interface where the interaction of sea and land processes occurs, shall be used instead.

Delineation of coastal zone is the first step to be taken in the process of spatial planning of the coastal areas. The National Physical Plan - Coastal Zone (NPP-CZ) [8] encompasses the land area extending 5 kilometers from the Mean High Water Level (MHWL), the sea extending 3 nautical miles from the Mean Low Water Level (MLWL), and the intertidal zone between the mean high and low water levels. Since the impact of coastal processes are more 
significant within the first 1 kilometer land area extending from the MLWL as proposed by the NPP-CZ, the area of the coastline and the edge of the river. study will focus to the 1 kilometer land area, extending from

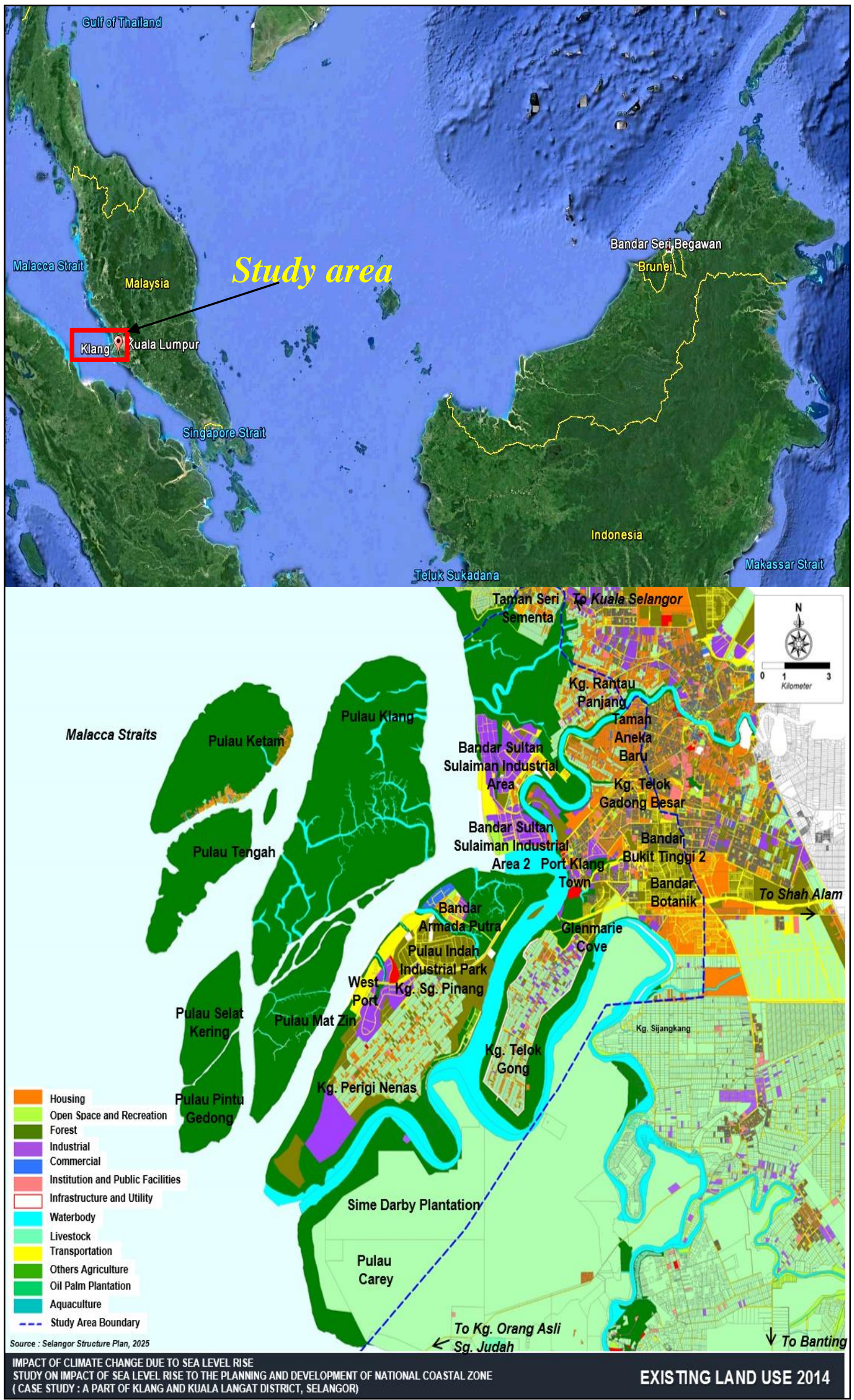

Fig. 1. Study area. 
TABLE I: THREE SCENARIOS OF PROPOSED STUDY BOUNDARY

\begin{tabular}{lll}
\hline \hline Boundary Consideration & Acreage (Ha) & \multicolumn{1}{c}{ Note } \\
\hline As proposed by NAHRIM & $37,011.4$ & - \\
As designated by NPP-CZ & $51,821.4$ & $\begin{array}{l}\text { To cover up to } 5 \mathrm{~km} \\
\text { inland }\end{array}$ \\
$\begin{array}{l}\text { With Mukim as the } \\
\text { boundary }\end{array}$ & $80,966.0$ & $\begin{array}{l}\text { To cover all Mukims } \\
\text { areas }\end{array}$ \\
\hline \hline
\end{tabular}

\section{B. Methodology}

The projected SLR for Klang coastal area obtained from the earlier study was incorporated in the numerical model to simulate hydrodynamic in SLR condition (as shown in Table II). Numerical model is a suitable tools to assess the impacts of SLR in water level magnitudes changes. An advantage of inundation model for vulnerability mapping is that they are relatively inexpensive to run, where some only require internet access; while others require Geographic Information System (GIS) software and sea level projection [9]. The numerical model software used in this study is MIKE 21 Flexible Mesh 2011 version. Digital Terrain Model (DTM) with resolution of $30 \mathrm{~m}$ and approximate $300 \mathrm{~m}$ width from water edge was integrated with the model bathymetry to produce detail and updated bathymetry profile.

According to Warren and Bach [10], MIKE 21 is a two dimensional microcomputer based modeling system for estuaries, coastal waters, and seas. It is also a professional engineering software package for modeling of flows, water levels, waves, sediment, and pollutant transport and water quality.

\section{RESULTS AND DISCUSSION}

The changes of water level magnitudes around Klang and Kuala Langat coastal area have clearly indicates imminent changes in hydrodynamic condition for year 2020, 2040 and 2060. Fig. 2 to 7 indicate obvious changes in water level and magnitudes of change in hydrodynamic. From the numerical simulation results, the maximum water level for 2012 is between $1.8-2.0$ meter (represent existing condition), indicates that some areas in Bagan Teochew (north east of Pulau Ketam) has already been inundated by sea water (Fig. 2 ). The maximum projected water level around Klang and Kuala Langat Districts for 2020, 2040 and 2060 varies from $1.35-2.0$ meter, $1.6-2.5$ meter and $2.0-2.5$ meter, respectively. Similarly, in 2080 and 2100, maximum water level arround the study area is expected to increase between $2.3-2.7$ meter and $2.6-2.9$ meter, respectively. Highest water level is expected to occur near the north east of Pulau Klang i.e above 2.9 meters. This indicates that almost all existing settlement at Pulau Ketam will be affected in the year 2080 and 2100.

\begin{tabular}{cl}
\multicolumn{2}{l}{ TABLE II: INCREASE IN SLR FROM MAXIMUM WATER LEVEL (MLWL) } \\
\hline \hline Year & \multicolumn{1}{c}{ Level (meter) } \\
\hline Baseline $(2014)$ & X meter \\
2020 & $X+0.06$ meter $(2.362$ inch) \\
2040 & $X+0.18$ meter (7.086 inch) \\
2060 & $X+0.29$ meter (11.417 inch) \\
2080 & $X+0.41$ meter (16.141 inch) \\
2100 & $X+0.53$ meter (20.866 inch) \\
\hline \hline
\end{tabular}

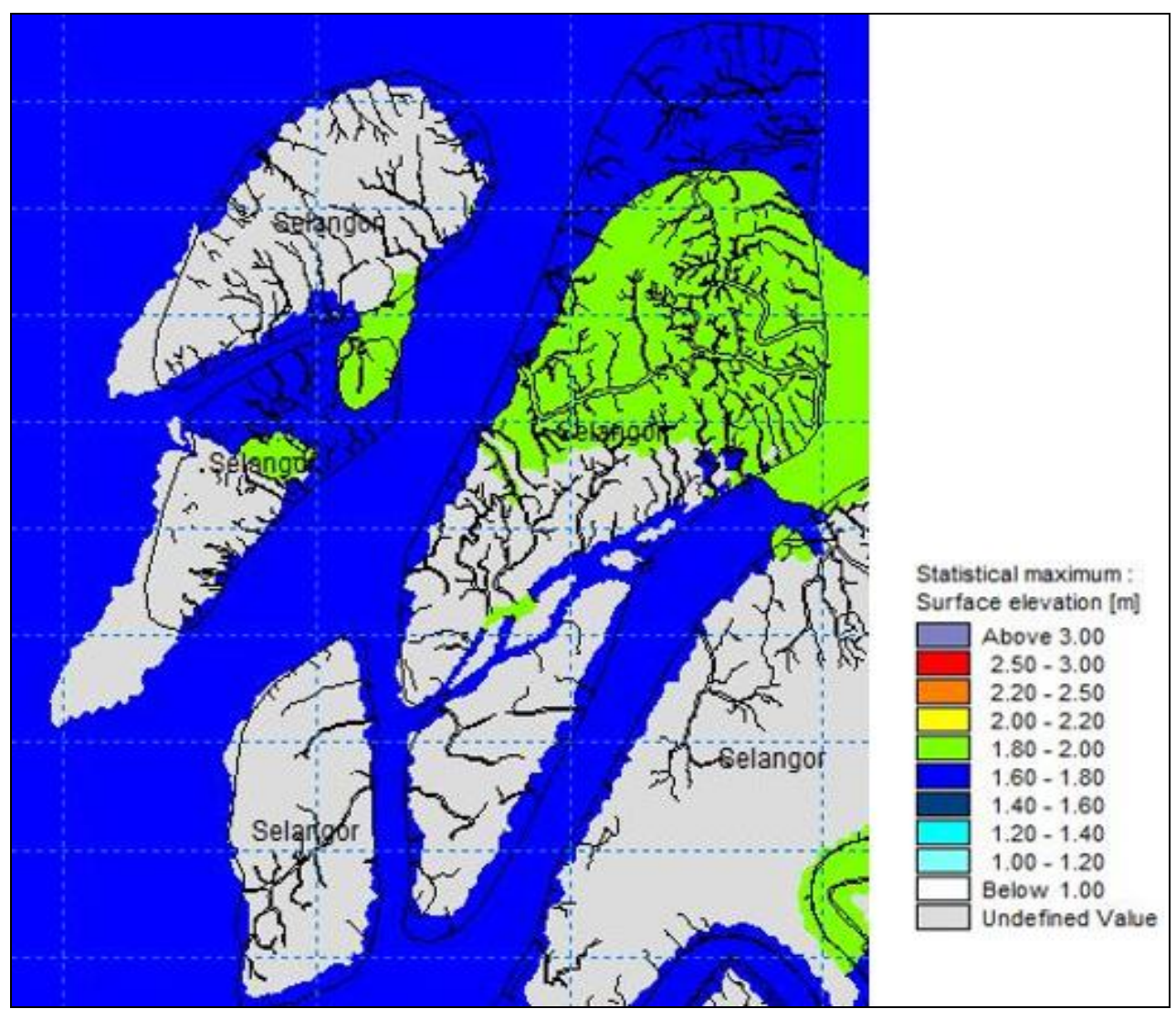

Fig. 2. Maximum sea level rise in year 2012 (existing). 


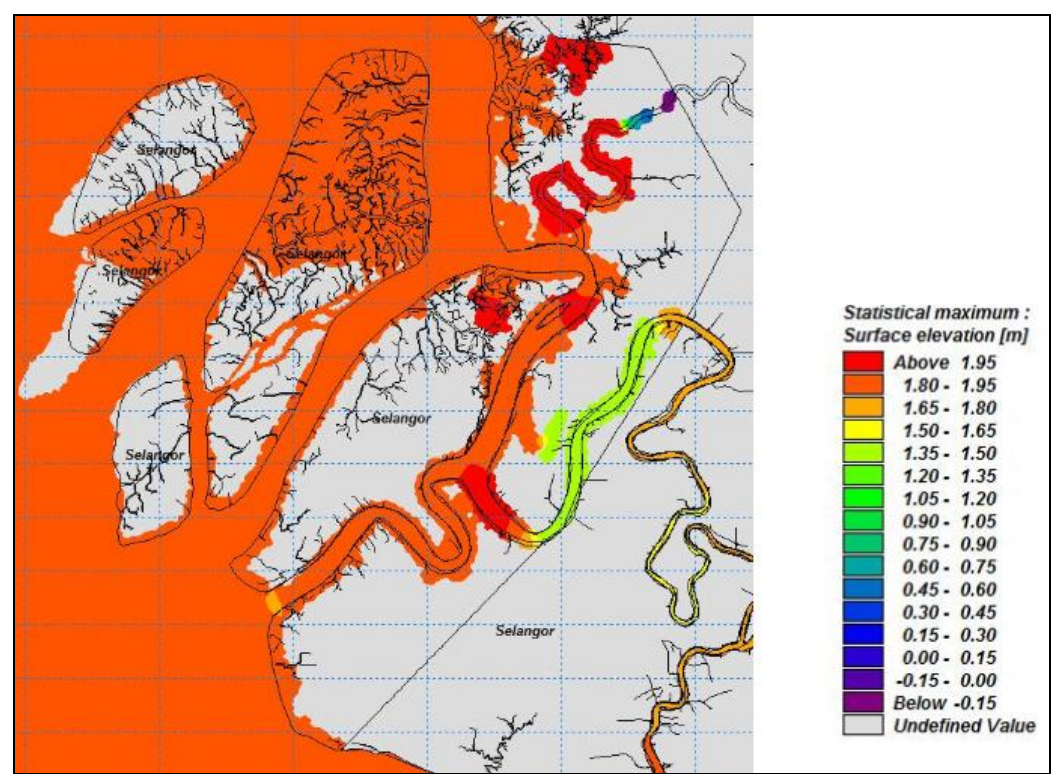

Fig. 3. Maximum sea level rise in year 2020 .

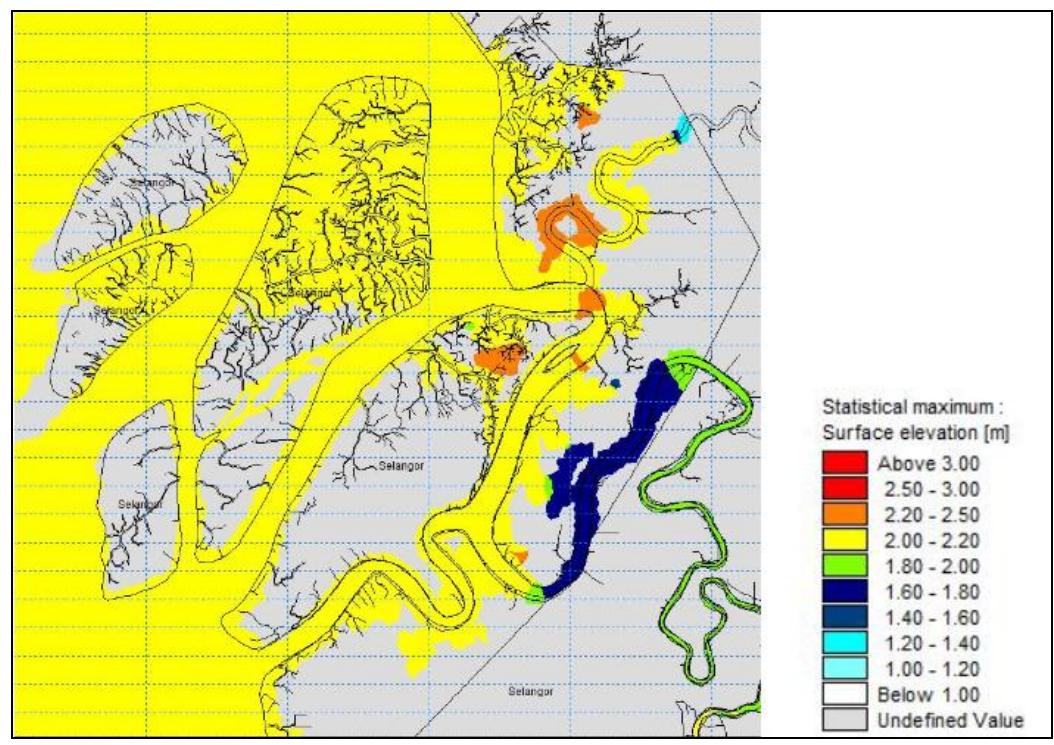

Fig. 4. Maximum sea level rise in year 2040 .

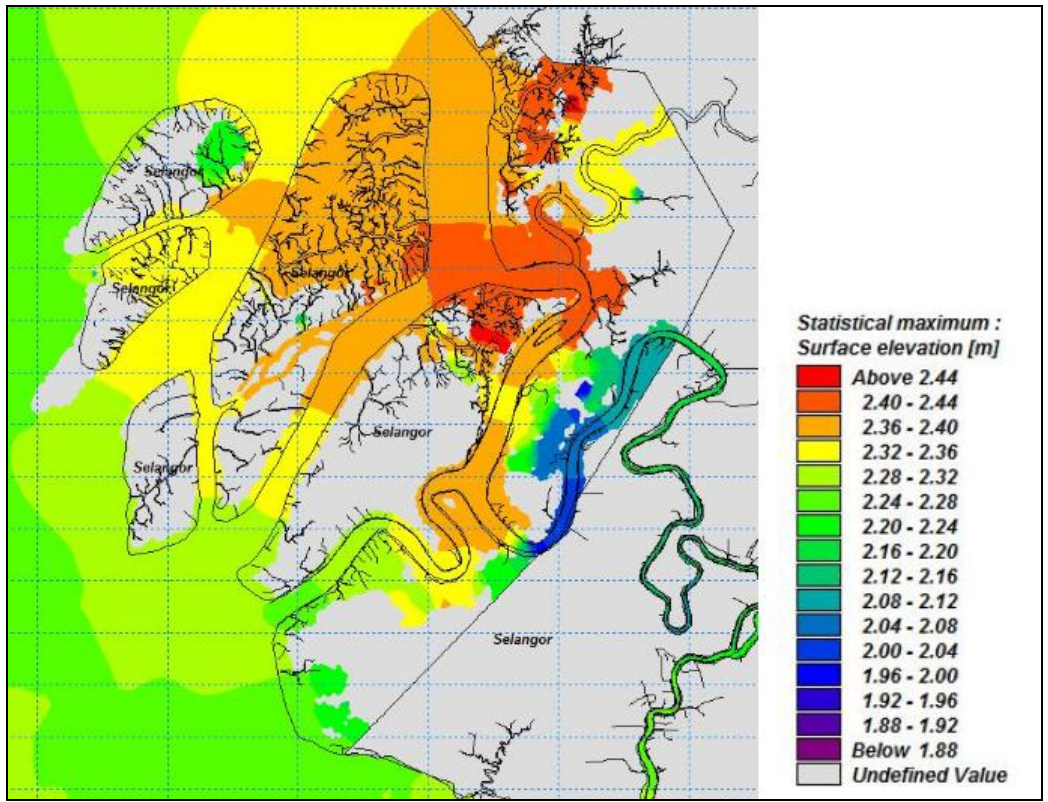

Fig. 5. Maximum sea level rise in year 2060 . 


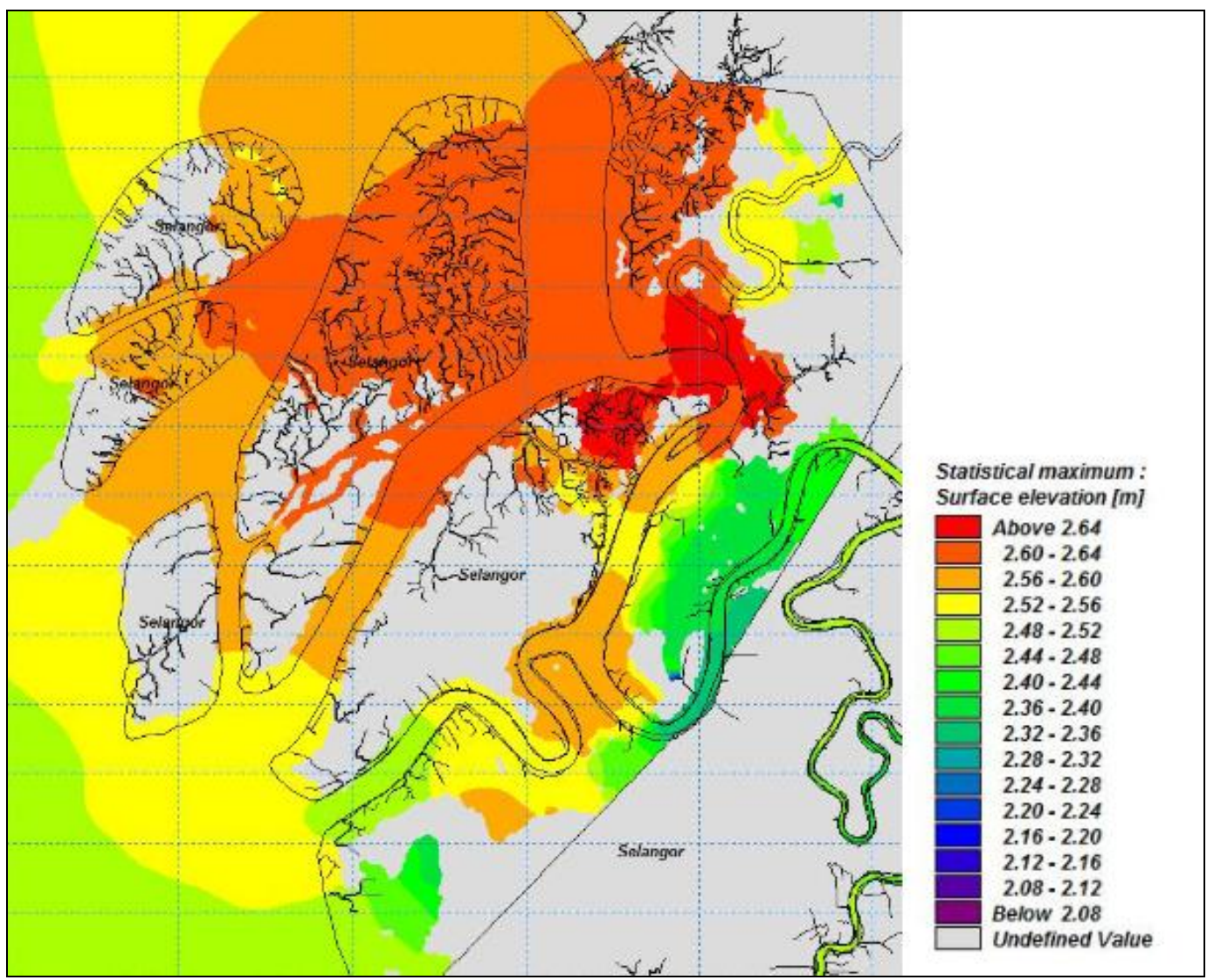

Fig. 6. Maximum sea level rise in year 2080.

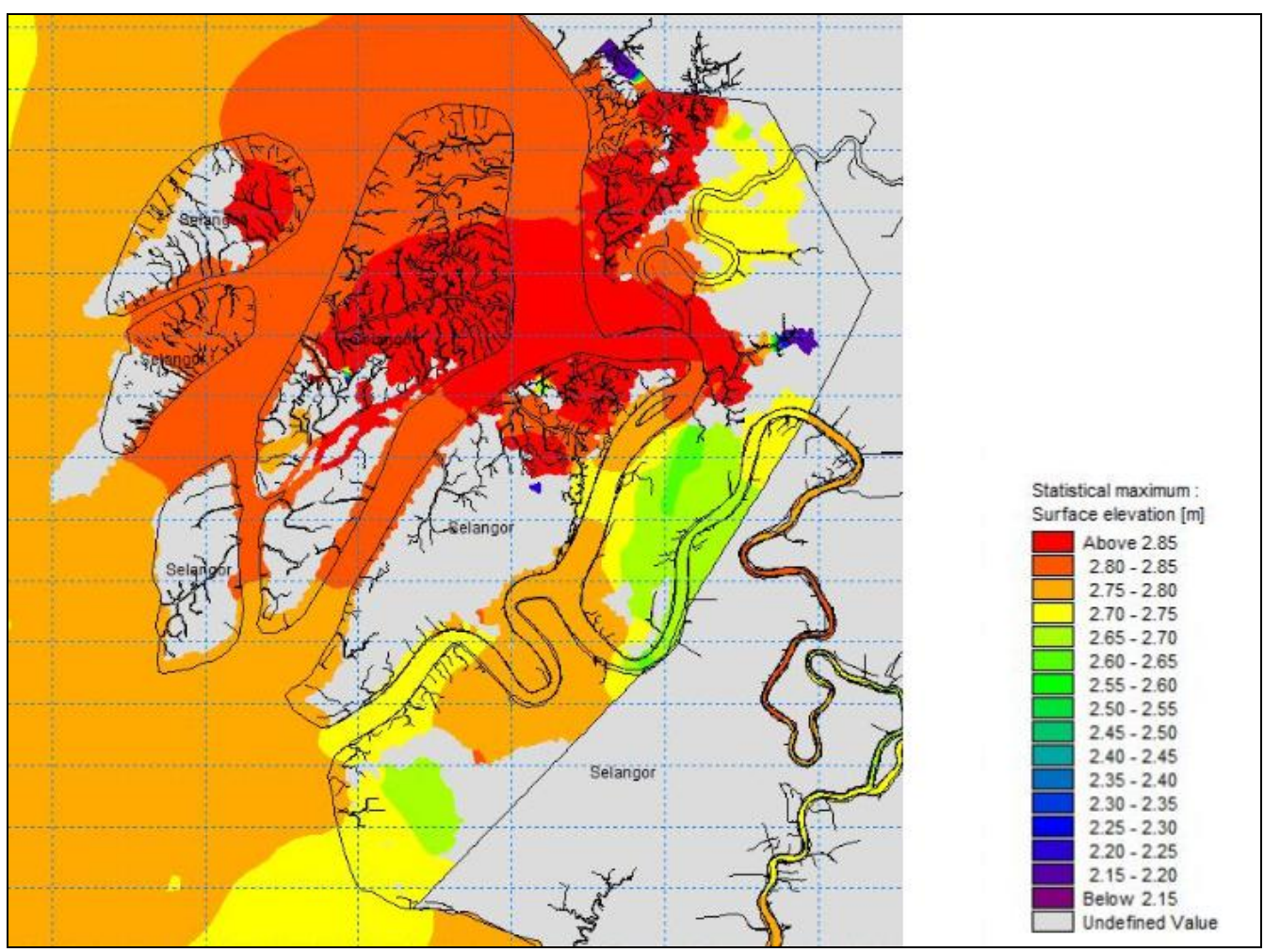

Fig. 7. Maximum sea level rise in year 2100 .

The modelling results shows that the water level in the study area is slowly increasing from year 2012 towards 2100 . These situation will give negative impacts to the development and the socio-economics of the coastal area. The low lying area such as Teluk Gong, Pulau Ketam, Pulau Mat Zin and Pulau Indah have already been inundated by the existing maximum water level (2012) which is in the range of 1.35 2.00 meter.

The projection of SLR for year 2020 for Klang area shows that the maximum water level will be rising in the range of 0.06 to 0.5 meter above the current water level [7]. In year 2100 , the maximum sea water level will projected to increase 
from 1.8 meter (2012) to about 3.0 meters. The potential inundated areas in 2100 are North Port, Bandar Sulaiman, Pulau Indah, Pulau Ketam, Pulau Tengah, Pulau Klang, Jalan Kem and Pendamaran, Teluk Gong and Kuala Langat.

The flood prone maps show some areas will be inundated by sea level rise. The areas that will be affected by the flooding from SLR in year 2100 are mainly the existing flood prone areas, which are low lying areas along Klang river and Langat river.The landuse type of these area are mostly housing and industrial. In most of the inundated area, the topographic condition of the land along the coastline are higher compared to those area near the river, thus the impact of SLR will mainly affecting the areas along the river. Klang known as royal city and former capital state of Selangor while Port Klang is a town and the main gateway by sea into Malaysia. The Port Klang which is located in Klang District is the $13^{\text {th }}$ busiest trans-shipment port. It is strategically located within the Klang valley, and it's distance of about $32 \mathrm{~km}$ from Kuala Lumpur city centre. Therefore, if areas like Port Klang and Bandar Sulaiman has the potential to be inundated, the socio-economy of the area will be significantly affected as it is an important place for economic activities in Klang.

Meanwhile, the protected area for mangrove at Pulau Klang and Pulau Ketam, are rich with mangrove forest and wetland. These areas are prone to sea level rise inundation due to very low lying. Apart from the low topography, the lack or poor management of drainage and irrigation are also found to be the main reason occurring at sub-urban and rural area, which is normally located within the potential inundated area such as Teluk Gong Village.

Climate change and sea level rise can give rise to high impacts such as destruction of assets and disruption to economic sectors, loss of human lives, mental health effects, or loss of plants, animals, and ecosystem and their severity depends on their extremes, exposure and vulnerability [11], [12]. Sea level rise may reduce the size of an island or state and its' infrastructure i.e. airports, roads, and capital cities, which normally predominate in the coastal areas; worsen inundation, erosion, and other coastal hazards; threaten vital infrastructure, settlements, and facilities; and thus compromise the socio-economic wellbeing of the island communities and states [13].

\section{CONCLUSION AND WAY FORWARD}

Hydrodynamic numerical model for Klang and Kuala Langat Districts are simulated and major impact are predicted due to sea level rise and climate change based on innundated map in year 2100. Sea level rise has the potential to change coastal natural processes, marine habitats and ecosystems, which will affect the infrastructure and thence the socio-economy of Malaysia. These impacts or disasters may be minimized or avoided with knowledge and preparedness. Since the Fifth Assessment Report (AR5) of the Intergovernmental Panel on Climate Change (IPCC) was finalized in 2014, a review of the existing sea level rise projections could be prepared with reference on the new findings of AR5. A lot of detailed studies are important to be undertaken in Malaysia on climate change and sea level rise related issues such as the potential inundation maps for sea level rise in other critical locations throughout Malaysia, vulnerability index for sensitive areas, assessment of potential impacts of climate change on other vulnerable sectors such as agriculture, forestry, biodiversity, water resources, coastal and marine resources, public health and energy.

\section{ACKNOWLEDGMENT}

The authors acknowledge the Coastal Management and Oceanography Research Centre, National Hydraulic Research Institute of Malaysia for the study undertaken.

\section{REFERENCES}

[1] R. K. Pachauri and A. Reisinger, "IPCC fourth assessment report," IPCC, Geneva, 2007.

[2] A. C. John, J. M. Gregory, N. J. White, S. M. Platten, and J. X Mitrovica, "Understanding and projecting sea level change," Oceanography 24, no. 2, pp. 130-143, 2011.

[3] C. Anny and R. S. Nerem, "Present-day sea level change: Observations and causes," Reviews of Geophysics, no. 3, 2004.

[4] C. A. John, N. J. White, R. Coleman, K. Lambeck, and J. X. Mitrovica, "Estimates of the regional distribution of sea level rise over the 1950-2000 period," Journal of Climate, no. 13, pp. 2609-2625, 2004.

[5] C. A. John and N. J. White, "A 20th century acceleration in global sea-level rise," Geophysical Research Letters no. 1, 2006

[6] Bindoff, L. Nathaniel, Jürgen Willebrand, Vincenzo Artale, Anny Cazenave, et al., "Observations: oceanic climate change and sea level," 2007.

[7] NAHRIM, The Study of the Impact of Climate Change on Sea level Rise in Malaysia, Final Report, December 2010.

[8] Federal Department of Town and Country Planning, Peninsular Malaysia, National Physical Plan-2. FDTCP, Ministry of Housing and Local Government, Kuala Lumpur, 2010.

[9] M. Elizabeth, J. Hinkel, A. T. Vafeidis, R. J. Nicholls et al., "Sea-level rise vulnerability in the countries of the Coral Triangle," Sustainability Science 5, no. 2, pp. 207-222, 2010.

[10] I. R. Warren, and H. K. Bach, "MIKE 21: A modelling system for estuaries, coastal waters and seas," Environmental Software 7, no. 4, pp. 229-240, 1992.

[11] IPCC, 2014: Climate Change 2014: Synthesis Report. Contribution of Working Groups I, II and III to the Fifth Assessment Report of the Intergovernmental Panel on Climate Change [Core Writing Team, R.K Pachauri and L.A. Meyer (eds.)]. IPCC, Geneva, Switzerland, pp. 151, 2014.

[12] R. McLean, "Impacts of weather, climate and sea level-related extremes on coastal systems and low-lying islands," IPCC Working Group II Scoping Meeting: Possible Special Report on Extreme events and Disasters: Managing the Risks, Oslo, Norway, 23-26 May 2009.

[13] H. John, Y. Honda, Z. W. Kundzewicz, N. Arnell et al., "Changes in impacts of climate extremes: human systems and ecosystems," Managing the Risks of Extreme Events and Disasters to Advance Climate Change Adaptation Special Report of the Intergovernmental Panel on Climate Change, pp. 231-290, 2012.

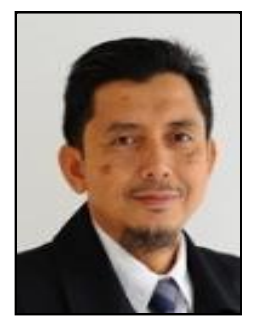

M. F. Mohamad was born in 1959 and holds a diploma in civil engineering at Institut Teknologi MARA, Malaysia in 1981, a bachelor of science (hons) in civil engineering at University of Strathclyde, United Kingdom (1983) and a master in hydrology and water resources at Universiti Teknologi Malaysia in 2009.

He had served at Public Work Department (PWD) from 1983 to 2001, before serving National Hydraulic Research Institute of Malaysia (NAHRIM) from 2001 to present. At PWD, he held positions of Senior Executive Engineer before serving at NAHRIM as a senior researcher on coastal engineering division on 2001 to 2003 and the director of hydraulic and instrumentation laboratory from 2003 until 2016. Currently, he is deputy director of Nahrim. Ir. M. F. Mohamad have vast experience in project management and structural design with major in coastal structures during his tenure in JKR and has produces several research technical papers. He is a professional engineer, a Member of Board of Engineer Malaysia (BEM); and 
Corporate Member, Institution of Engineer Malaysia (IEM).

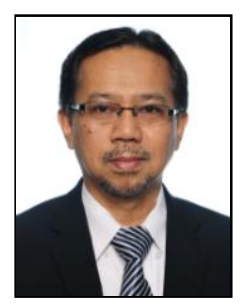

M. R. Abd Hamid is currently the director of the Coastal Management and Oceanography Research Centre, National Hydraulic Research Institute of Malaysia (NAHRIM). Over the past 25 years, he has worked on civil, structural and coastal engineering including hydrodynamic modeling for mangrove replanting, coastal erosion and sea level rise in Malaysia. He obtained his diploma in civil engineering from Universiti Teknologi MARA, Malaysia. Then, he pursued for his bachelor degree at the University of Hartford, United State of America (USA). Ir. M. R. Abd Hamid have vast experience in project management and structural design with major in coastal structures during his tenure in PWD and has produces several research technical papers. He is a Professional Engineer, Member of Board of Engineer Malaysia (BEM); and Corporate Member, Institution of Engineer Malaysia (IEM).

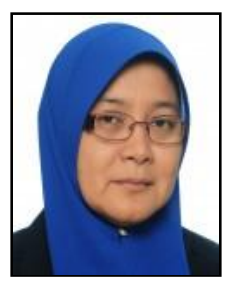

N. A. Awang is currently the senior research officer attached with the coastal management and oceanography research Centre, National Hydraulic Research Institute of Malaysia (NAHRIM). Over the past 13 years, she has worked on hydrodynamic modeling for mangrove replanting, coastal erosion and sea level rise in Malaysia. She graduated in civil engineering from Universiti Teknologi MARA, Malaysia. Then, she pursued her studies at University of Waikato, New Zealand where she earned a master in earth sciences.

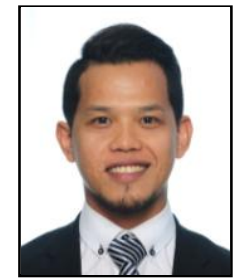

A. Md. Shah is currently the Senior Research Officer attached with the Coastal Management and Oceanography Research Centre, National Hydraulic Research Institute of Malaysia (NAHRIM). Over the past 9 years, he has worked on hydrodynamic modeling, coastal erosion, coastal vulnerability index and sea level rise in Malaysia. He graduated in marine science from Universiti Malaysia Terengganu (UMT), Malaysia. Then, he pursued his studies at Universiti Kebangsaan Malaysia (UKM), Malaysia where he earned a master in MARINE science.

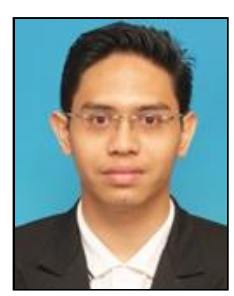

A. F. Hamzah was born in Kuala Lumpur, Malaysia, in 1986. He received the B.Sc. and M.Sc. degree in civil engineering from the Universiti Teknologi MARA, Malaysia, in 2007 and 2011, respectively; and currently a Ph.D. candidates in civil engineering at the Universiti Tun Hussein Onn Malaysia, Johor, Malaysia.

In 2012, he joined Faculty of Civil Engineering, Universiti Teknologi MARA Pulau Pinang as a Lecturer, and in 2015, became a research officer at National Hydraulic Research Institute of Malaysia (NAHRIM). His current research interests include major discipline of civil engineering, materials and structures. Mr. Hamzah is a graduate member of the Institute of Engineer Malaysia (IEM) and the Board of Engineer Malaysia (BEM). 